\title{
Women and strength training
}

\author{
Trenig silowy kobiet
}

\begin{abstract}
Strength training does not constitute women's favourite physical activity. It is demonstrated in the survey conducted by Budzyńska at the University of Szczecin in 2013 among students of the Pedagogical Faculty. Only 1\% of the surveyed students showed interest in strength training. The vision of a bodybuilding silhouette discourages women from taking up strength training. It is displayed in the survey conducted by Zaustowska in 2001 among junior high school students. Out of 78 respondents, 71 stated that they did not like the muscular figure. These fears are unfounded since a woman's body is not disposed to achieve a bodybuilding figure. It depends on the structural, morphological and biochemical properties of one's body. Some women who practice bodybuilding rely on strength training additionally supporting the growth of muscle mass with nutrients.

This paper presents the advantages of applying strength training in everyday physical activity. These include fat reduction and a slim figure. Furthermore, the result of strength training is a relative increase in muscle mass and strength development. Another benefit of this form of activity is the strengthening of the structures which stabilize joints and bones thus reducing the risk of injury.

The duration of static exercise depends on the applied load. Due to the short duration of static effort and relatively high strength commitment, energy for working muscles comes from anaerobic changes. ATP, phosphocreatine and a small amount of glycogen which are hydrolyzed. During the static exercise blood pressure and heart rate are increased. These changes are dependent on the size of the strength developed to oppose resistance. A heavy load used during the static exercise often causes reflex respiratory arrest, a dangerous phenomenon resulting in fainting during the exercise.
\end{abstract}

Keywords: woman, silhouette, strength training, effort, mass

\section{STRESZCZENIE}

Trening siłowy będący w dużej mierze wysiłkiem statycznym nie należy do ulubionych form aktywności fizycznej kobiet. Dowiodła tego ankieta przeprowadzona przez Budzyńską na Uniwersytecie Szczecińskim w 2013 roku wśród studentek kierunku pedagogicznego. Zainteresowanie treningiem siłowym wykazało zaledwie $1 \%$ ankietowanych studentek. Kobiety do wysiłków siłowych zniechęca wizja kulturystycznej sylwetki. Potwierdzają to badania ankietowe przeprowadzone przez Zaustowską w 2001 roku wśród gimnazjalistek. Na 78 badanych, 71 stwierdziło, że nie podoba im się umięśniona sylwetka. Obawy te są bezpodstawne, gdyż organizm kobiety nie jest usposobiony do osiągania figury kulturystycznej. Mają na to wpływ właściwości strukturalne, morfologiczne i biochemiczne organizmu. Część kobiet uprawiających kulturystykę bazuje na treningu siłowym dodatkowo wspomagając przyrost masy mięśniowej odżywkami.

W pracy przedstawiono korzyści wynikające z uwzględnienia treningów siłowych $\mathrm{w}$ codziennej aktywności fizycznej. Należą do nich m.in. redukcja tkanki tłuszczowej i ukształtowanie smukłej sylwetki. Ponadto efektem treningu siłowego jest relatywny wzrost masy mięśniowej oraz rozwój siły. Inną zaletą tej formy aktywności jest wzmocnienie struktur stabilizujących stawy i kości zmniejszając tym samym ryzyko urazu.

Czas wysiłku statycznego jest uzależniony od wielkości zastosowanego obciążenia. Ze względu na krótki czas trwania wysiłku statycznego i stosunkowo dużego zaangażowania siłowego, energia dla pracujących mięśni pochodzi z przemian beztlenowych. Hydrolizie ulega ATP, fosfokreatyna i niewielka ilość glikogenu. W trakcie wysiłku statycznego dochodzi do wzrostu ciśnienia krwi oraz tętna. Zmiany te są uzależnione od wielkości rozwiniętej siły do przeciwstawienia się oporowi. Duże obciążenia podczas wysiłku statycznego często powodują odruchowe zatrzymanie oddechu, jest to zjawisko niebezpieczne skutkujące omdleniem w czasie ćwiczenia.

Słowa kluczowe: kobieta, sylwetka, trening siłowy, wysiłek, masa 


\section{INTRODUCTION}

Exercising at the gym is one of the activities that are rarely chosen by women with an active lifestyle. Women prefer fitness, aerobics, dancing, cycling, regular visits to the swimming pool, etc. This thesis is confirmed by the results of studies conducted by Budzyńska. In November and December 2013, a group of 300 pedagogical students at the University of Szczecin, aged 20-25, underwent a survey on their preferred physical activity. These studies show that $29 \%$ of female students attend fitness, $17 \%$ run regularly, and $9 \%$ cycle [1].

The prospect of a bodybuilding figure discourages women from undertaking cyclical strength efforts. Women live with the conviction that working with weights will shape their athletic body type. From a female point of view, such a state of affairs can significantly affect the negative perception of one's attractiveness.

Zaustowska (2001) conducted a survey among girls from middle school classes [2]. The survey was to evaluate their approach to strength training. 78 girls participated in the study. They were asked for their opinion on 2 a bodybuilder's body. 71 girls replied that 2 a bodybuilder figure did not suit them. In turn, in the eyes of 6 girls, this figure was appreciated, while one person did not define herself. In a survey of 37 girls, a bodybuilding figure is not considered to be very feminine. A group of 16 middle school girls think they have too much muscle. According to 10 girls, the figure is characterized by small breasts, and 8 students say that such an appearance is unsightly [2]. This study, conducted on relatively young girls, shows the skeptical approach of the female gender to a muscular figure. There does not appear to be any other reason that distances women from regular strength efforts, such as struggling with heavy weights.

Dannelly et al. (2011) assessed the effectiveness of female strength training based on closed and open chain kinematic exercises [3]. The traditional model of strength exercises and exercises with the use of tapes were used. The 26 volunteers were divided into two groups, randomly assigned to two different forms of training. 6 sets of exercises were prescribed for 13 weeks. They were based on functional tests consisting in squeezing out the maximum load for the lower limbs and upper limbs (push-ups) at one time. In addition, an equilibrium test (Star Excursion) was performed. The following results were obtained. Women improved bench press by an average of 4-6 kg and leg press by an average of 23-35 kg. Balance improved in both groups [3].

Edholm et al. (2017) assessed the effectiveness of 24 weeks of strength training in combination with a healthy diet for lower limb strength in older women [4]. The participants were divided into three research groups. Resistance training (RT), resistance training with a healthy diet (RT-HD) and the control group (CON). The load of progressive resistance training was determined on the basis of a single rep- etition of the maximum load. The training load value is 75$85 \%$. The change in the diet consisted primarily of a change in the PUFA ratio (n6/n3). Lean body mass increased in the RT-HD group. There was an improvement in the power of knee straightening muscles both in the RT group $(+15.7 \pm$ 2.6 and $-11.0 \pm 3.8 \%)$ and RT-HD $(+24.6 \pm 2.6$ and $-20.3 \pm$ $2.7 \%)$. However, the RT-HD group performed better. The same was true for the development of strength during the squat jump. RT-HD group (+58.5 \pm 8.4 and $+185.4 \pm 32.9 \%)$, RT group (+35.7 \pm 6.9 and $+105.4 \pm 22.4 \%)$ [4] .

Trzaskoma (2003) assessed the maximum moments of muscle strength in the lower limbs, upper limbs and torso [5]. In the case of absolute values, the difference is $37 \%$, while the disproportion of relative values is $24.4 \%$. Slightly smaller disproportions between men and women were noted in the strength of the muscles of the lower extremities. The difference in absolute values is $31.7 \%$, while in relative values it is $18.3 \%$. There are also significant disproportions in the values of the maximum strength of the trunk muscles. Thus, the difference in the absolute value is $26.9 \%$ and in the relative value $11.7 \%$. Trzaskoma (2003) summed up the results obtained of the maximum moments of strength of the studied muscle groups and defined them as total force, which in women is characterized by lower absolute values (by 31.6\%) and relative values (by 18.1\%) than in men. The most significant disproportion between a woman and a man is noted in the strength of the flexor muscles of the elbow joint. Respectively, absolute values$0.8 \%$, relative values $-29.1 \%$. In turn, the smallest differences are in the strength of the muscle groups responsible for straightening the torso, absolute values $-26.1 \%$, relative values $-11.1 \%$. During strength exertion, a woman obtains lower values of maximum moments of strength in the muscles of the lower limbs, upper limbs and torso compared to men. Significant differences between the two genders in absolute parameters and relative strengths take place in the strength of the muscles of the upper limbs [5].

Fitness tests conducted by Jaskólski (2006) show that that the maximum oxygen uptake in women is $25-30 \%$ lower than in men [6]. Converting this into kg of body weight, the disproportions decrease to the level of $20 \%$, while taking into account people with a slim figure, the difference in the level of $\mathrm{VO}_{2 \max }$ ranges from $5 \%$ to $11 \%$. The disproportions that exist between the two sexes $\mathrm{VO}_{2 \max }$ are mainly due to differences in the amount of adipose tissue in the total body weight. Moreover, studies have shown that the average maximum oxygen uptake in a mature woman fluctuates between 33-42 $\mathrm{ml} / \mathrm{kg} / \mathrm{min}$, and in men 43-52 $\mathrm{ml} / \mathrm{kg} / \mathrm{min}$ [6].

The stereotype of a muscular figure among women as a result of regular strength training is a myth. A woman's body is not predisposed to shaping an athletic figure. There are several supporting arguments for this thesis. Well, both sexes differentiate between the body's structural, morpho- 
logical and biochemical factors. They have a direct impact on the quality of the results achieved. The hormonal economy plays an important role as it has the greatest influence on the tendency to increase muscle mass. Disproportions in the endocrine system directly interact for the period in which the development of muscle tissue culminates in both sexes. The main factor here is the concentration of testosterone in the blood, which is much lower in women than in men. The greatest development of muscle tissue in women takes place at the age of 16-20. In the case of men, this applies to the period of 18-25 years, with possible later progress [7]. Blood testosterone levels are an important factor in the development of muscle hypertrophy. Without the use of various types of nutrients or anabolic steroids, women are not able to achieve an overly muscular figure.

The distribution of body fat is different for both sexes. In women it constitutes $25 \%$ of the total weight and in men 15\%. [7]. The hips, buttocks, thighs, and back of the arms are characteristic places of fat cell deposition in women. The female hormone, i.e. estrogen together with lipoprotein lipase, is responsible for this process. The overactivity of this enzyme in the above-mentioned around the body causes the penetration of triglycerides into fat cells in the region of increased activity of lipoprotein lipase [6]. Therefore, exercises with weights along with aerobic efforts will perfectly reduce body fat. In addition, strength training is not only about shaping the body, increasing muscle mass, but also increasing strength. In addition, the effect is the improvement of general physical fitness, mental condition, strengthening of bones, ligamentous apparatus, joint capsules, tendons and muscles. As a result, the susceptibility and the risk of locomotor injuries are reduced.

Among women who are supporters of a sports lifestyle, there are many whose goal is to achieve a muscular figure. They are usually women, who practice bodybuilding and take part in competitions of this sport on a regular basis. The essence of this type of competition is to present the best figure possible i.e. extensive muscle tissue with as little adipose tissue as possible. Then, the jurors evaluate the following elements: muscles, proportions, symmetry, presentation and muscle structure [8]. In the case of women, it is more difficult to build muscle mass due to the lack of structural, morphological and biochemical predispositions of the body, unlike men. Therefore, a very important element of the training process, apart from systematic work in the gym, is a well-balanced diet and various types of nutrients that support muscle hypertrophy.

\section{AIM}

The aim of the study is to present anthropometric and morphological differences as fundamental factors influencing the quality of the effects obtained.

\section{THE DIFFERENCE IN EFFORT BETWEEN A MAN AND A WOMAN}

Different responses to exercise between the two sexes result from differences in anthropometric indices. A very important element influencing exercise reactions in both sexes is the size of muscle mass and anthropometric indicators (including body height). Hence, $\mathrm{VO}_{2 \max }$ and muscle strength in women are characterized by lower values than in men [6].

During submaximal exercise $\left(<100 \% \mathrm{VO}_{2 \max }\right)$, there is no disproportion in oxygen uptake between women and men. It is characteristic for women that during exercise they work at a higher percentage of the maximum oxygen uptake $\left(\mathrm{VO}_{2 \max }\right)$, which results in an increased concentration of lactate in the blood serum.

In women, during exercise with specific oxygen, there is an increased activation of free fatty acids (FFA) and limited use of glucose. This process depends on the female sex hormones, estrogen and progesterone [6].

During moderate exercise, cardiac output is similar in both sexes. However, there are differences in the components of cardiac output. Namely, in women, the heart rate is higher and the stroke volume is lower. The maximum heart rate in both sexes is similar. Both in untrained and training women, the maximum value of cardiac output does not exceed $25 \mathrm{l} / \mathrm{min}$. This value is significantly smaller than in men, whose capacity may reach 30-35 1/min. During maximum load efforts, the stroke volume of the heart is lower in women than in men [6].

The arteriovenous difference in oxygen content and cardiac output determine the $\mathrm{VO}_{2 \max }$ value. Due to the fact that a woman is characterized by a small body structure, less muscle mass, the size of the heart muscle will also be smaller. Given that the size of the stroke volume is dependent on the size of the heart it can be concluded that the magnitude of the maximum intake oxygen is lower in women than in men. These disproportions decrease when converted into $\mathrm{kg}$ of body weight. [6]

The dimensions of the body determine the amount of lung ventilation, therefore in women the vital capacity of the lungs as well as the tidal volume are much smaller. Both these values account for $50-80 \%$ of the average value of men. During high-load exercise, women have a greater number of breaths (50-60/min) than men (40-50/min). Minute lung ventilation in women is also reduced due to the smaller tidal volume. Clear disproportions are noted in the values of maximum lung ventilation (MVV) in both sexes. MVV in women is about $100 \mathrm{l} / \mathrm{min}$, while in men it is more than $150 \mathrm{l} / \mathrm{min}[6]$.

Muscle mass determines a person's anaerobic capacity. Due to the lower muscle mass of women, they are characterized by much lower anaerobic capacity than men. The Wingate test is used to assess anaerobic capacity, the essence of which is a 30 -second effort characterized by the 
greatest possible intensity, performed on a cycloergometer at a specific resistance $(\mathrm{N})$. Anaerobic capacity is assessed on the basis of the a maximum power obtained and the work performed (per kg of body weight) [9]. The difference in the concentration of lactic acid in the blood serum between a woman and a man is mainly due to the lower muscle mass of women. It is unlikely that the disproportion in blood lactate concentration depends on the degree of glycolytic enzyme activity, as both sexes show similar levels of their activity. As a result of exercise, increased activity of some enzymes was observed in women, including phosphorylase and lactate dehydrogenase [6].

\section{ADAPTATION TO TRAINING OF MEN AND WOMEN}

Under the influence of strength training, men and women have comparable values of muscle strength. The thesis is confirmed by the research carried out by Jaskólski [6], to which men and women were subjected after an identical 10 -week training. Namely, the increase in strength in the attempt of bench press increased in women by $29 \%$, and in men by $17 \%$. In the case of the squat in women by $30 \%$, and in men by $26 \%$. The increase in muscle mass in women was not as significant as in men. The female muscular hypertrophy was mild. The significant increase in strength that has been observed in women is explained by the action of neurodegenerative factors, including increased recruitment of motor units. The most visible effects of strength training in the form of increased strength are noticed in people whose initial strength level is low [6].

The adaptation process to endurance training is similar in both sexes. The level of $\mathrm{VO}_{2 \max }$, increases and its increase it is mainly determined by an increase in cardiac output (Q) and an increase in the number of capillaries supplying a single myocyte. As a result of increasing the above-mentioned components in women with long training experience, the maximum level of oxygen uptake is 65-68 $\mathrm{ml}$ per $\mathrm{kg}$ of body weight.

Myocardial growth occurs as a result of endurance training. Under the influence of oxygen-specific training, the maximum oxygen consumption in women may increase by 10$50 \%$, i.e. to the values similar to those achieved by men [6].

\section{EFFECT OF STRENGTH TRAINING ON CHANGES IN MUSCLE MASS}

Following regular strength training, it is noted, inter alia, an increase in muscle mass and strength. In women, much less muscle growth is observed than in men. It is determined by morphological and biochemical conditions and 2 the structure of the body.

Muscle hypertrophy, also referred to as muscle hypertrophy, is characterized by an increase in the volume of myocytes and an increase in their mass. This process does not increase the number of muscle fibers. The main stimulus for muscle growth is physical effort, especially with a specific strength. Muscle hypertrophy is caused by the formation of new myofibrils. In addition, muscle hypertrophy is significantly influenced by the division of stem cells and bonding with the present myocytes, as a result of which the number of cell nuclei in the myocyte increases. In these nuclei, actin and myosin proteins are synthesized for the resulting myofibrils. During intense exercise, microtraumas occur, which stimulate the stem cells to divide. Similar processes are used in the regeneration of muscle fibers after an injury [10].

The response of the muscular system to applied strength training is skeletal muscle hypertrophy. Fast-twitch and slow-twitch fibers are hypertrophied, but fast fibers to a greater extent. The greatest muscle hypertrophy is observed in people who started strength training without having been exposed to this type of effort before. The amount of muscle growth depends on the type of exercise, the load used, the intensity and the number of training units in a given time. Contractile proteins located in myocytes are subject to continuous processes of synthesis and degradation. The prerequisite for muscle hypertrophy is the domination of protein synthesis over degradation processes. Protein metabolism is stimulated by exercise. Protein transformations take place 24-48 hours after exercise [10].

The endocrine system may be one of the many factors contributing to muscle hypertrophy. As a consequence of resistance exercise, the level of anabolic hormones in the blood serum increases significantly. It is believed that testosterone in particular can stimulate specialized receptors, leading to muscle hypertrophy. This thesis is to be confirmed by research carried out by Czarkowska-Pęczek in people who have undergone strength training [10]. Well, the size of muscle hypertrophy is closely related to the level of testosterone in the blood. Insulin is another hormone that significantly affects protein metabolism.

Its tasks include stopping the degradation of proteins, it does not affect their synthesis to a large extent [10].

It is speculated that the increase in muscle mass is a consequence of post-exercise damage to the muscle fibers. The microtrauma and inflammation resulting from strength exertion stimulate regenerative mechanisms that increase the volume of the muscle. Following this concept, the training should be based on eccentric exercises, because they favor the formation of significant microtraumas of muscle fibers than in the case of concentric exercises [10].

As muscle mass increases, the force of contraction increases. Namely, the increase in contractile force is commensurate with the cross section of the muscle fiber.

The speed at which a muscle shortens depends on the content of the type of muscle fibers. 
In relation to the correlation between the myocyte cross-section and contraction force, this force is determined by the myofibril density in the muscle fiber. Thus, fast-twitch and slow-twitch fibers differ in the strength of their contraction. The research carried out by Czarkowska-Pęczek confirms that, as a result of strength training, the increase in the strength of contraction of a single myocyte is proportional to its enlarged cross-section [10]. These studies may suggest an increased number of proteins in the muscle cell, however, data confirming changes in the volume of myofibrils in the muscle fiber are lacking. Strength training affects the speed of shortening of all types of muscle fibers [10].

A very important element supporting the growth of muscle mass is a properly balanced diet. Proteins found in muscles are constantly degraded and synthesized. Amino acids are used up as part of the resynthesis process (about 80\%) obtained from the breakdown of proteins. The remaining amount of amino acids (approx. 20\%) for the synthesis of muscle protein comes from the food you eat. As is known, the synthesis processes dominate the processes of muscle protein degradation after exercise. Therefore, providing the right amount of amino acids is an important element conducive to increasing muscle mass. Strength training does not bring effects in the form of increased muscle mass when the diet contains too little essential amino acids [10].

\section{SUMMARY}

Strength-specific physical activity is not popular among most women due to the prevailing stereotype of develop- ing an athletic figure. Therefore, women consciously avoid strength efforts by choosing other forms of physical activity, e.g. dancing, aerobics, cycling and swimming. This confirms the opinion that women are unaware of the impossibility of shaping a muscular figure. Strength training brings many beneficial changes in the body, which should encourage women to engage in regular activities of this type. One of them is the reduction of body fat and the increase of muscle mass. This results in obtaining an attractive figure. In addition, strength efforts improve overall physical fitness, strengthen bones, ligament apparatus, joint capsules and muscles. This reduces the risk of injury.

\section{REFERENCES / LITERATURA}

1. Ali Sudani A, Budzyńska K. Aktywność fizyczna studentek-motywy podejmowania i zachowania antyzdrowotne. Wychowanie Fizyczne i Zdrowotne. 2014;5:10-13.

2. Zaustowska B. Aktywność fizyczna a uroda. Lider. 2007;5:21-23.

3. Dannelly BD, Otey SC, Croy T, et al. The Effectiveness of Traditional and Sling Exercise Strength Training in Women. Journal of Strength and Conditioning Research. 2011;25(2):464-471.

https://doi.org/10.1519/JSC.0b013e318202e473

4. Edholm P, Strandberg E, Kadi F. Lower limb explosive strength capacity in elderly women: effects of resistance training and healthy diet. J Appl Physio. 2017;123(1):190-196.

https://doi.org/10.1152/japplphysiol.00924.2016

5. Trzaskoma Z. Maksymalna sita mięśniowa i moc maksymalna kobiet i mężczyzn uprawiajacych sport wyczynowo. Warszawa: Wyd. AWF; 2003.

6. Jaskólski A, Jaskólska A. Podstawy fizjologii wysitku fizycznego z zarysem fizjologii człowieka. Wrocław: Wyd. AWF; 2006.

7. Ronikier A. Fizjologia sportu. Warszawa: Centralny Ośrodek Sportu; 2001.

8. Mizieliński S. Kulturystyka. Warszawa: Wyd. Sport i Turystyka; 1987.

9. Górski J, ed. Fizjologia wysitku i treningu fizycznego. Warszawa: Wyd. PZWL; 2012.

10. Czarkowska-Pączek B, Przybylski J. Zarys fizjologii wysitku fizycznego. Wrocław: Wyd. Urban \& Partner; 2006. 